\title{
Evaluating the portals of Iran ministries using the Standard WebQEM
}

Komeil Shahvari

Department of Computer \& Information Technology, Payame Noor University (PNU), PO Box 19395-4697, Tehran, Iran

k.shahvari@gmail.com

Editor Científico: José Edson Lara

Organização Comitê Científico

Double Blind Review pelo SEER/OJS

Recebido em 06.05.2019

Aprovado em 22.06.2019

Este trabalho foi licenciado com uma Licença Creative Commons - Atribuição - Não Comercial 3.0 Brasil 


\begin{abstract}
The present study was done to evaluate the quality of portals in Iran ministries using "WebQEM". The research was descriptive and the method was web metrics. The research community is 13 portals of Iran Ministries. The required data was collected using a checklist designed based on a web-based quality evaluation method. Data analysis was performed using SPSS-21 software. After evaluating the main criteria using the Web quality evaluation method and considering the average scores obtained for four main indices, it is concluded that the portals examined had more weaknesses in terms of functionality and usability, which required a closer look. In the case of two indices of reliability and performance, almost all sites had a very good and high score. The designers of these portals should focus on these weaknesses and try to resolve them.
\end{abstract}

Keywords: WebQEM, Quality Evaluation, Iran Ministries, E-Government

\title{
Avaliação dos portals dos Ministérios do Irã usando o Padrão WebQEM
}

\section{Resumo}

O presente estudo foi feito para avaliar a qualidade dos portais nos ministérios do Irã usando "WebQEM". A pesquisa foi descritiva e o método foi métrica da web. A comunidade de pesquisa é de 13 portais dos ministérios do Irã. Os dados necessários foram coletados usando uma lista de verificação projetada com base em um método de avaliação de qualidade baseado na web. A análise dos dados foi realizada no software SPSS-21. Após avaliar os principais critérios utilizando o método de avaliação da qualidade da Web e considerando os escores médios obtidos para quatro índices principais, conclui-se que os portais analisados apresentaram mais fragilidades em termos de funcionalidade e usabilidade, o que exigiu um olhar mais atento. No caso de dois índices de confiabilidade e desempenho, quase todos os sites tiveram uma pontuação muito boa e alta. Os projetistas desses portais devem se concentrar nesses pontos fracos e tentar resolvê-los.

Palavras-chave: WebQEM, Avaliação da Qualidade, Ministérios do Irã, Governo Eletrônico

\section{Evaluación de los portales de ministerios de Irán mediante el WebQEM Estándar}

\section{Resumen}

El presente estudio se realizó para evaluar la calidad de los portales en los ministerios de Irán utilizando "WebQEM". La investigación fue descriptiva y el método fue la métrica web. La comunidad de investigación son 13 portales de los Ministerios de Irán. Los datos requeridos se recopilaron utilizando una lista de verificación diseñada en base a un método de evaluación de calidad basado en la web. El análisis de datos se realizó utilizando el software SPSS-21. Después de evaluar los criterios principales utilizando el método de evaluación de la calidad web y considerando los puntajes promedio obtenidos para cuatro índices principales, se 
concluye que los portales examinados tenían más debilidades en términos de funcionalidad y usabilidad, lo que requirió una mirada más cercana. En el caso de dos índices de fiabilidad y rendimiento, casi todos los sitios obtuvieron una puntuación muy buena y alta. Los diseñadores de estos portales deberían centrarse en estas debilidades e intentar resolverlas.

Palabras clave: WebQEM, Evaluación de calidad, Ministerios de Irán, Gobierno electrónico

\section{Introduction}

The increasing advances in information technology have led to many changes in various areas of human life. These improvements, such as faster computing, availability of information, easy maintenance of a large volume of information, the ability to exchange data at long intervals, etc. can make various activities more efficient and faster. However, the level of error or data manipulation has been reduced significantly. Many activities can be improved with the help of information technology such as communications, education, management and commerce. Also, information technology can be used to communicate between the government and people and provide services to people, called e-government.

The concept of e-government is equivalent to providing the easy use of information technology for distribution of government services directly to the customer, twenty-four hours and seven days a week. The e-government means using the technology to facilitate the government affairs through providing efficient and effective information and services to citizens and business and manufacturing companies.

The ministries' portals are one of the communication portals between people and the government that people can visit to get the services. Proper design and proper provision of services on these portals is effective in establishing proper communication between the government and people and increasing the satisfaction of people. In this research, the status of Iranian ministries' portals is measured in terms of the various variables to determine their quality in service delivery.

\section{Literature review}

In the last years, the topic of portal evaluation has attracted the attention of researchers inside of the country and abroad. We need a good standard for evaluating the websites and portals, but so far the standard has not been developed and approved by everyone. The various 

WebQEM

researchers have used the different methods to evaluate the websites and portals. One of the methods used to evaluate the websites is the WebQEM evaluation method, first used by Louise Olsina and Gustav Rossi in 1999. This methodology designed based on the quality model standard for the evaluation of software (ISO 9126-1), a version of which has been used to carry out the modifications to evaluate the websites in this study. This method of portals evaluation has been used in various researches. In a research and entitled "Creating a quality model based on the site evaluation process", Biscoglio et al. used the existing qualitative model as a template. Ancut (2009), in a research entitled "The Image of Investment and Financial Services Companies in WWW Landscape (World Wide Web)" reviewed Romania's websites of investment and financial services companies using WebQEM. Mehri Saeed et al. (2011) used the WebQEM method in their paper titled "Rank-Order Weighting of Web Attributes for Website Evaluation" at Petra University, Malaysia. Militaru (2011), used WebQEM method to evaluate the quality of some Romanian University websites. Subramaniam et al. (2011), have used the WebQEM method in a study entitled "Quality Evaluation of Malaysia Online Fast Food Restaurant Websites, ".

Various researches have been conducted in the country with this method. Pashazadeh and Hajji Zainalabedini in their article " WebQEM, a Quantitative Approach for Quality Evaluation of Librarian Web sites" (2009); Mohammad Esmaeil Khanlarkhani in his article "Quality evaluation of web pages of research institutes affiliated to the Ministry of Science and Research and Technology based in Tehran from the users' perspective" (2009); Ali Bik et al. In his article "Qualitative evaluation of the websites of Central Libraries of Iranian Medical Sciences Universities using WebQEM Method" (2011), are among those who have used the WebQEM method in their researches. Also, Daghale et al. in a research entitled "Qualitative Evaluation of the Portals for the Subsidiaries of Iran Ministry of Petroleum Using Web Qi" (2014); Gharibe Niyazi et al. in his article "Evaluation of the websites of Iran state universities under the supervision of the Ministry of Science and Technology and Research in the WebQEM method" (2016), used the web-based method in their researches. Therefore, the WebQEM -based method is a well-known and widely used method for researchers, especially in Iran.

With reviewing the researches in the field of web metrics and website quality evaluation, it is worth noting that much attention has not been paid to the field of government portals and little researches have been done in this field; for example, Qaem Montazer and Shams in their article "Evaluation of Iranian Government Web Bases at Three Levels of Information, Communication and Transaction: Comparing Two Periods 2005 and 2010" have studied the quality of Iranian 
government websites (2015); in that article, they used the model of the UNESCO Electronic Governance Analysis, therefore seems necessary the research in this field.

\section{Research objectives}

General Objective: Assessing the quality of the ministries' portals of the Islamic Republic of Iran.

1- Evaluation of Iran ministries' portals based on the indices of "usability"

2. Evaluation of Iran ministries' portals based on the indices of "functionality"

3. Evaluation of Iran ministries' portals based on the indices of "reliability"

4. Evaluation of Iran ministries' portals based on the indices of "efficiency"

5. General evaluation of Iran ministries' portals based on four indices of web evaluation using WebQEM

\section{Research Question}

How are Iran ministries' portals in terms of the four indices of WebQEM method evaluation?

\section{Methodology}

The present study method is survey and evaluation. The statistical population consists of 18 ministries' websites of the Islamic Republic of Iran. The library method has been used to develop the theoretical foundations. The check list is based on researches done by Olsina et al. (1999) in the WebQEM-based method. This list contains four main variables for evaluating the website that several sub-variables have been used to measure each of them. These four variables, which are actually considered as core criteria for website evaluation, are "usability", "performance", "reliability" and "efficiency". The "usability" criterion has been evaluated based on sub criteria such as "global site understandability", "feedback and help features", "interface and aesthetic features" and "miscellaneous features" such as support for other languages and the latest update index.

The "reliability" criterion has been evaluated based on the non-defective technical criteria and the efficiency criterion through the measurement of the "performance behavior" and "accessibility" sub-criteria, and finally the "functionality" criterion through the sub criteria 

WebQEM

"searching and retrieving issues", "navigation and browsing issues" and "domain specific functionality and content".

To measure each major criterion, the measurement began with the most detailed sub criteria related to that criterion' in the way that for sub criteria, a coefficient which is a number between zero and one, is considered in terms of their importance. Then, with observing the portal's position by the researcher, a score was considered for that sub criteria. Thus, the actual score of each sub criteria was calculated by multiplication of points assigned by the researcher in its importance coefficient. Diagram 1 shows a number of computational operations to determine the main score corresponding to that criterion. Scores for each main criterion are between zero and one, and the raw data in this research are scores given by the researcher to the sub criteria.

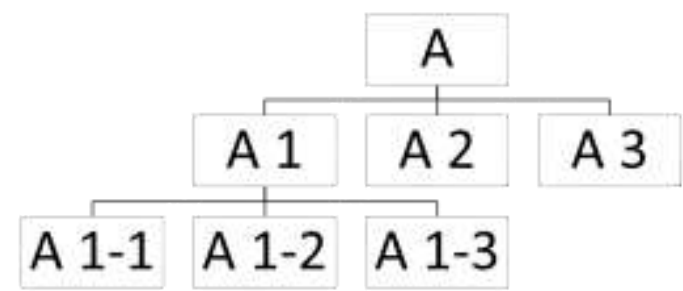

Figure 1. Calculation a criterion based on sub criteria

These data were saved as a data file in SPSS-21 software, and the subsequent analysis was calculated using this software. At first, the scores related to the main criteria and sub criteria for the portal evaluation were calculated and then the scores obtained in the five groups were categorized as follows: Very undesirable (from 0 to 0.2 ), undesirable (from 0.21 to 0.4 ), average (from 0.41 to .0 .6 desirable (from 0.61 to 0.8 ) and very desirable (from 0.81 to 1 ). The weight assigned to each criterion, based on its importance, was determined based on the knowledge of the researcher and consultation with field experts. Then, the information obtained from the processing of scores was prepared and adjusted in descriptive tables for answering the research question.

\section{Results}

Table 1, shows the findings related to the usability criterion. $60 \%$ of sites are in a very desirable position and only $5 \%$ are in a very bad position in terms of understanding criteria. The overall average indicates the average position of the sites in terms of "feedback and help features,", and the distribution of data also shows that 90 percent of the sites received a score in 40-80 range. Almost $90 \%$ of the sites are in a desirable position in terms of "interface and 
aesthetic features", and they have won a high average score in terms of the miscellaneous features of most sites. In the overall evaluation of sites in terms of usability, about $60 \%$ of the sites are in a favorable condition and about $27 \%$ are in the middle position.

Table 1

Evaluating the Portals of Iran Ministries related to the usability criterion

\begin{tabular}{|c|c|c|c|c|c|c|c|c|c|c|}
\hline $\begin{array}{l}\text { The } \\
\text { main }\end{array}$ & \multicolumn{10}{|c|}{ Usability } \\
\hline \multirow[t]{2}{*}{$\begin{array}{l}\text { Sub } \\
\text { criterion }\end{array}$} & \multicolumn{2}{|c|}{$\begin{array}{c}\text { Global Site } \\
\text { Understandabilit } \\
\mathrm{y}\end{array}$} & \multicolumn{2}{|c|}{$\begin{array}{l}\text { Feedback and } \\
\text { help features }\end{array}$} & \multicolumn{2}{|c|}{$\begin{array}{l}\text { Interface and } \\
\text { Aesthetic } \\
\text { Features }\end{array}$} & \multicolumn{2}{|c|}{$\begin{array}{l}\text { Miscellaneous } \\
\text { Features }\end{array}$} & \multicolumn{2}{|c|}{$\begin{array}{l}\text { General } \\
\text { evaluation }\end{array}$} \\
\hline & $\begin{array}{l}\text { Numb } \\
\text { ers }\end{array}$ & $\begin{array}{l}\text { Percent } \\
\text { age }\end{array}$ & $\begin{array}{l}\text { Numb } \\
\text { ers }\end{array}$ & $\begin{array}{l}\text { Percent } \\
\text { age }\end{array}$ & $\begin{array}{l}\text { Numb } \\
\text { ers }\end{array}$ & $\begin{array}{l}\text { Percent } \\
\text { age }\end{array}$ & $\begin{array}{l}\text { Numb } \\
\text { ers }\end{array}$ & $\begin{array}{l}\text { Percent } \\
\text { age }\end{array}$ & $\begin{array}{l}\text { Numb } \\
\text { ers }\end{array}$ & $\begin{array}{l}\text { Percent } \\
\text { age }\end{array}$ \\
\hline $\begin{array}{l}\text { Very } \\
\text { desirabl } \\
\text { e }\end{array}$ & 8 & 44.4 & 1 & 5.6 & 1 & 5.5 & 4 & 22.2 & 1 & 5.6 \\
\hline $\begin{array}{l}\text { desirabl } \\
\mathrm{e}\end{array}$ & 3 & 16.7 & 5 & 27.8 & 16 & 89 & 7 & 38.9 & 11 & 61.1 \\
\hline average & 3 & 16.7 & 6 & 33.5 & 1 & 5.5 & 4 & 22.2 & 5 & 27.8 \\
\hline $\begin{array}{l}\text { undesira } \\
\text { ble }\end{array}$ & 3 & 16.7 & 5 & 27.8 & 0 & 0 & 2 & 11.1 & 1 & 5.6 \\
\hline $\begin{array}{l}\text { Very } \\
\text { undesira } \\
\text { ble }\end{array}$ & 1 & 5.6 & 1 & 5.6 & 0 & 0 & 1 & 5.6 & 0 & 0 \\
\hline sum & 18 & 100 & 18 & 100 & 18 & 100 & 18 & 100 & 18 & 100 \\
\hline $\begin{array}{l}\text { Lowest } \\
\text { score }\end{array}$ & \multicolumn{2}{|c|}{0.16} & \multicolumn{2}{|c|}{0.19} & \multicolumn{2}{|c|}{0.59} & \multicolumn{2}{|c|}{0.2} & \multicolumn{2}{|c|}{0.35} \\
\hline $\begin{array}{l}\text { highest } \\
\text { score }\end{array}$ & \multicolumn{2}{|c|}{0.86} & \multicolumn{2}{|c|}{0.85} & \multicolumn{2}{|c|}{0.81} & \multicolumn{2}{|c|}{0.95} & \multicolumn{2}{|c|}{0.83} \\
\hline average & \multicolumn{2}{|c|}{0.64} & \multicolumn{2}{|c|}{0.52} & \multicolumn{2}{|c|}{0.76} & \multicolumn{2}{|c|}{0.64} & \multicolumn{2}{|c|}{0.65} \\
\hline $\begin{array}{l}\text { The } \\
\text { standard } \\
\text { deviatio } \\
\mathrm{n}\end{array}$ & \multicolumn{2}{|c|}{0.24} & \multicolumn{2}{|c|}{0.18} & \multicolumn{2}{|c|}{0.06} & \multicolumn{2}{|c|}{0.22} & \multicolumn{2}{|c|}{0.13} \\
\hline
\end{tabular}

In table 2, the results are related to the " Functionality " criterion, which in terms of "searching and retrieving issues " about 38 percent of the sites have a favorable and very desirable position, and more than 60 percent of sites have a moderate or lower status. All sites are in a desirable and desirable position in terms of navigation and browsing issues. In the "domain specific functionality and content" section, about half of the sites are in a desirable and very desirable position, and the other half are average and lower. Overall, $95 \%$ of sites are in a high position in terms of "performance capability" and about 50 percent are in a desirable and very desirable position. 
Table 2

Evaluating the Portals of Iran Ministries related to the functionality criterion

\begin{tabular}{|c|c|c|c|c|c|c|c|c|}
\hline The main & \multicolumn{8}{|c|}{ Functionality } \\
\hline \multirow[t]{2}{*}{$\begin{array}{l}\text { Sub } \\
\text { criterion }\end{array}$} & \multicolumn{2}{|c|}{$\begin{array}{c}\text { Searching and } \\
\text { Retrieving Issues }\end{array}$} & \multicolumn{2}{|c|}{$\begin{array}{l}\text { Navigation and } \\
\text { Browsing Issues }\end{array}$} & \multicolumn{2}{|c|}{$\begin{array}{c}\text { Domain Specific } \\
\text { Functionality and } \\
\text { Content }\end{array}$} & \multicolumn{2}{|c|}{ General evaluation } \\
\hline & Numbers & $\begin{array}{c}\text { Percent } \\
\text { age }\end{array}$ & $\begin{array}{c}\text { Number } \\
\mathrm{S}\end{array}$ & $\begin{array}{c}\text { Percentag } \\
\mathrm{e}\end{array}$ & $\begin{array}{c}\text { Number } \\
\mathrm{S}\end{array}$ & $\begin{array}{c}\text { Percentag } \\
\mathrm{e}\end{array}$ & $\begin{array}{c}\text { Number } \\
\mathrm{S}\end{array}$ & $\begin{array}{c}\text { Percentag } \\
\mathrm{e}\end{array}$ \\
\hline $\begin{array}{l}\text { Very } \\
\text { desirable }\end{array}$ & 5 & 27.8 & 11 & 61.1 & 2 & 11.1 & 3 & 16.7 \\
\hline desirable & 2 & 11.1 & 7 & 38.9 & 7 & 38.9 & 6 & 33.4 \\
\hline average & 5 & 27.8 & 0 & 0 & 4 & 22.2 & 8 & 44.4 \\
\hline $\begin{array}{l}\text { undesirabl } \\
\text { e }\end{array}$ & 4 & 22.2 & 0 & 0 & 2 & 11.1 & 1 & 5.6 \\
\hline $\begin{array}{l}\text { Very } \\
\text { undesirabl } \\
\text { e }\end{array}$ & 2 & 11.1 & 0 & 0 & 3 & 16.7 & 0 & 0 \\
\hline sum & 18 & 100 & 18 & 100 & 18 & 100 & 18 & 100 \\
\hline $\begin{array}{l}\text { Lowest } \\
\text { score }\end{array}$ & \multicolumn{2}{|c|}{0} & \multicolumn{2}{|c|}{0.69} & \multicolumn{2}{|c|}{0.14} & \multicolumn{2}{|c|}{0.38} \\
\hline $\begin{array}{l}\text { highest } \\
\text { score }\end{array}$ & \multicolumn{2}{|c|}{0.9} & \multicolumn{2}{|c|}{0.95} & \multicolumn{2}{|c|}{0.88} & \multicolumn{2}{|c|}{0.88} \\
\hline average & \multicolumn{2}{|c|}{0.54} & \multicolumn{2}{|c|}{0.82} & \multicolumn{2}{|c|}{0.56} & \multicolumn{2}{|c|}{0.63} \\
\hline $\begin{array}{l}\text { The } \\
\text { standard } \\
\text { deviation }\end{array}$ & \multicolumn{2}{|c|}{0.29} & \multicolumn{2}{|c|}{0.08} & \multicolumn{2}{|c|}{0.23} & \multicolumn{2}{|c|}{0.16} \\
\hline
\end{tabular}

Table 3 shows the findings on "reliability", which is highly desirable in all sections, including "link errors" and "miscellaneous errors or drawbacks" and in general, the "reliability" of the sites is very high and appropriate.

Table 3

Evaluating the Portals of Iran Ministries related to the reliability criterion

\begin{tabular}{|c|c|c|c|c|c|c|}
\hline The main & \multicolumn{6}{|c|}{ Reliability } \\
\hline \multirow[t]{2}{*}{ Sub criterion } & \multicolumn{2}{|c|}{ Link Errors } & \multicolumn{2}{|c|}{$\begin{array}{l}\text { Miscellaneous Errors or } \\
\text { Drawbacks }\end{array}$} & \multicolumn{2}{|c|}{ General evaluation } \\
\hline & Numbers & Percentage & Numbers & Percentage & Numbers & Percentage \\
\hline Very desirable & 18 & 100 & 17 & 94.4 & 18 & 100 \\
\hline desirable & 0 & 0 & 1 & 5.6 & 0 & 0 \\
\hline average & 0 & 0 & 0 & 0 & 0 & 0 \\
\hline undesirable & 0 & 0 & 0 & 0 & 0 & 0 \\
\hline $\begin{array}{l}\text { Very } \\
\text { undesirable }\end{array}$ & 0 & 0 & 0 & 0 & 0 & 0 \\
\hline sum & 18 & 100 & 18 & 100 & 18 & 100 \\
\hline Lowest score & \multicolumn{2}{|c|}{0.9} & \multicolumn{2}{|c|}{0.79} & \multicolumn{2}{|c|}{0.84} \\
\hline highest score & \multicolumn{2}{|c|}{0.9} & \multicolumn{2}{|c|}{1} & \multicolumn{2}{|c|}{0.95} \\
\hline average & \multicolumn{2}{|c|}{0.9} & \multicolumn{2}{|c|}{0.95} & \multicolumn{2}{|c|}{0.92} \\
\hline $\begin{array}{l}\text { The standard } \\
\text { deviation }\end{array}$ & \multicolumn{2}{|r|}{0} & \multicolumn{2}{|c|}{0.07} & \multicolumn{2}{|c|}{0.03} \\
\hline
\end{tabular}


Table 4 shows the status of sites in terms of "efficiency". Except for one, the rest of the sites are very good in terms of running. In terms of accessibility, the most sites are in the best position. In general, most sites are in a very desirable position in terms of performance. The only exception was the site "the Ministry of Foreign Affairs of the Islamic Republic of Iran", which needs special attention.

\section{Table 4}

Evaluating the Portals of Iran Ministries related to the efficiency criterion

\begin{tabular}{|c|c|c|c|c|c|c|}
\hline $\begin{array}{l}\text { The main } \\
\text { criterion }\end{array}$ & \multicolumn{6}{|c|}{ Efficiency } \\
\hline Sub criterion & \multicolumn{2}{|l|}{ Running } & \multicolumn{2}{|c|}{ Accessibility } & \multicolumn{2}{|c|}{ General Evaluation } \\
\hline & Numbers & Percentage & Numbers & Percentage & Numbers & Percentage \\
\hline Very desirable & 17 & 9404 & 2 & 11.1 & 17 & 94.4 \\
\hline desirable & 0 & 0 & 16 & 88.9 & 0 & 0 \\
\hline average & 0 & 0 & 0 & 0 & 1 & 5.6 \\
\hline undesirable & 1 & 5.6 & 0 & 0 & 0 & 0 \\
\hline $\begin{array}{l}\text { Very } \\
\text { undesirable }\end{array}$ & 0 & 0 & 0 & 0 & 0 & 0 \\
\hline sum & 18 & 100 & 18 & 100 & 18 & 100 \\
\hline Lowest score & \multicolumn{2}{|c|}{0.3} & \multicolumn{2}{|c|}{0.7} & \multicolumn{2}{|c|}{0.5} \\
\hline highest score & \multicolumn{2}{|c|}{1} & \multicolumn{2}{|c|}{0.85} & \multicolumn{2}{|c|}{0.94} \\
\hline average & \multicolumn{2}{|c|}{0.96} & \multicolumn{2}{|c|}{0.79} & \multicolumn{2}{|c|}{0.89} \\
\hline $\begin{array}{l}\text { The standard } \\
\text { deviation }\end{array}$ & \multicolumn{2}{|c|}{0.16} & \multicolumn{2}{|c|}{0.04} & \multicolumn{2}{|c|}{0.1} \\
\hline
\end{tabular}

In table 5, the comparison of four main criteria for evaluating portals shows us that the websites of the Iranian ministries are in a very desirable position in terms of reliability and efficiency. Most of these websites are desirable in terms of usability, and some are average. The lowest score is for performance, and this criterion has a lower rating than the rest of the criteria. 
Table 5

Evaluating the Portals of Iran Ministries using the Standard WebQEM

\begin{tabular}{|c|c|c|c|c|c|c|c|c|}
\hline \multirow{2}{*}{$\begin{array}{l}\text { The main } \\
\text { criterion }\end{array}$} & \multicolumn{2}{|c|}{ Usability } & \multicolumn{2}{|c|}{ Functionality } & \multicolumn{2}{|c|}{ Reliability } & \multicolumn{2}{|c|}{ Efficiency } \\
\hline & $\begin{array}{c}\text { Numbe } \\
\text { rs }\end{array}$ & $\begin{array}{c}\text { Percenta } \\
\text { ge }\end{array}$ & $\begin{array}{l}\text { Numbe } \\
\text { rs }\end{array}$ & $\begin{array}{c}\text { Percenta } \\
\text { ge }\end{array}$ & $\begin{array}{c}\text { Numbe } \\
\text { rs }\end{array}$ & $\begin{array}{c}\text { Percenta } \\
\text { ge }\end{array}$ & $\begin{array}{c}\text { numbe } \\
\text { rs }\end{array}$ & $\begin{array}{c}\text { percenta } \\
\text { ge }\end{array}$ \\
\hline $\begin{array}{l}\text { Very } \\
\text { desirable }\end{array}$ & 1 & 5.6 & 3 & 16.7 & 17 & 94.4 & 17 & 94.4 \\
\hline desirable & 11 & 61.1 & 6 & 33.4 & 1 & 5.6 & 0 & 0 \\
\hline average & 5 & 27.8 & 8 & 44.4 & 0 & 0 & 1 & 5.6 \\
\hline $\begin{array}{l}\text { undesira } \\
\text { ble }\end{array}$ & 1 & 5.6 & 1 & 5.6 & 0 & 0 & 0 & 0 \\
\hline $\begin{array}{l}\text { Very } \\
\text { undesira } \\
\text { ble }\end{array}$ & 0 & 0 & 0 & 0 & 0 & 0 & 0 & 0 \\
\hline sum & 18 & 100 & 18 & 100 & 18 & 100 & 18 & 100 \\
\hline $\begin{array}{l}\text { Lowest } \\
\text { score }\end{array}$ & \multicolumn{2}{|c|}{0.35} & \multicolumn{2}{|c|}{0.38} & \multicolumn{2}{|c|}{0.79} & \multicolumn{2}{|c|}{0.5} \\
\hline $\begin{array}{l}\text { highest } \\
\text { score }\end{array}$ & \multicolumn{2}{|c|}{0.83} & \multicolumn{2}{|c|}{0.88} & \multicolumn{2}{|c|}{1} & \multicolumn{2}{|c|}{0.94} \\
\hline average & \multicolumn{2}{|c|}{0.65} & \multicolumn{2}{|c|}{0.63} & \multicolumn{2}{|c|}{0.95} & \multicolumn{2}{|c|}{0.89} \\
\hline $\begin{array}{l}\text { The } \\
\text { standard } \\
\text { deviation }\end{array}$ & \multicolumn{2}{|c|}{0.13} & \multicolumn{2}{|c|}{0.16} & \multicolumn{2}{|c|}{0.07} & \multicolumn{2}{|c|}{0.1} \\
\hline
\end{tabular}

\section{Discussion and conclusion}

In the last years, the discussion on the evaluation of websites is one of the topics of concern to the researchers. One of the standards that is widely accepted among the scholars around the world is the WebQEM standard. In Iran, many researchers have also used the WebQEM-based approach in their researches. In this research, the web-sites of the Islamic Republic of Iran were evaluated using the WebQEM standard. After evaluating the main criteria using the WebQEM quality evaluation method and considering the average scores obtained for four main indices, it is concluded that the portals examined are weaker in terms of functionality and usability, which requires a closer look. In the case of two reliability and efficiency indices, almost all sites, with the exception of the State Department site, had a very high score. With analyzing the findings, it can be provided an adequate analysis of the state of the sites in terms of e-government.

According to the results of the survey, most sites are designed to look good. They have a low error rate and good performance. In general, sites work well. Another question is whether the sites are doing the right thing and are good for the task they are responsible for! Is there a 
decent online service available to users? In the "domain specific functionality and content" criterion, the subset of the "functionality" criteria, it has an average score. Most of the ministries' sites have been designed and implemented to play the role of public relations and present the organization's news. On most sites, a set of rules and guidelines for the general public was under the jurisdiction of the ministry. But there were very few sites on-line and transaction-based. Other pages were designed in this form. The page was not transactional and it is likely that the online services will be a part of the future plans of the ministry.

According to the results of the survey, it is necessary to create a change in the attitude of managers as well as the site designers so that the ministry's websites move from prioritizing news to the priority of online services. It is necessary to create a style sheet for online services of ministries and to update websites and services.

Also, the following suggestions are provided for the future researches:

Expert investigation of each ministry and its subsets using the WebQEM-based evaluation method.

Evaluation of the ministry's sites from the perspective of users

A survey of all government-related sites that are not subsets of the ministries, with the WebQEM

Research on the WebQEM methodology and the possibility of increasing the main and sub criteria

\section{References}

Alibeig M. R. Jamshidi Ork R. Hajizeinolabedi M. Pashazadeh F. (2011). Qualitative Assessment Of The Websites Of The Central Libraries Of Iran's Medical Universities Using The Webqem Method Of Health Management 14 (43): 63-75.

Ancut, Iancu Ioana. (2011). The Image of Investment and Financial Services Companies in WWW Landscape (World Wide Web). Annals of the University of Oradea: Economic Science 1 (1), 748-753.

Biscoglio, I, M. Fusani, G. Lami and G. Trentanni. (2009). Establishing a quality-model based evaluation process for websites. ISTI (Institute of Science and Technologies in Informatics) - CNR (National Research Council), Via Moruzzi 1, 56124 Pisa, Italy.

Daghlghe N. Bigdeli Z. Azimi M. H. (2014). Qualitative assessment of the portals of the subsidiaries of Iran's Oil Ministry, using Web-Qi Ayam, Journal of Information Processing and Management, Volume 29, Issue 4, pp. 1069-1089.

Gharibeh Niyazi M. Karbala Aghaie Kamran M. Ghaebi A. (2016). Evaluation of the websites of Iran's state universities under the supervision of the Ministry of Science, Research and Technology by WEBQEM, Journal of Library and Information Science Studies, No. 17, pp. 63-78. 
Hema Subramaniam, Rusli Abdullah, Nor Hafiza Mohd Zin, Mohammad Moein Almasi. (2013). Quality Evaluation of Malaysia Online Fast Food Restaurant Websites, World Academy of Science, Engineering and Technology 74 2013, 409-413.

Militaru, TL. (2011). The evaluation of the websites quality; application for the website of universities. The 3rd International Conference: Institutional Strategic Quality Management - ISQM2011.July 14 - 16, 2011, Sibiu, Romania Paper ID: 062-ISQM2011: 236-242.

Mohammad Esmail S. Khanlari E. (2009). Evaluation Of The Quality Of Web Pages Of The Research Institutes Affiliated To The Ministry Of Science, Research And Technology Based In Tehran From Users' Point Of View. Quarterly Journal of the Library, 87-108.

Montaaerghaem M. Shamsi M. (2015). Evaluation of Iranian Government Web Bases at Three Levels of Information, Communication and Transaction: Comparison of Two Periods 2005 and 2010, Journal of Information Processing and Management, Volume 31, Issue 1, Pages 163-191.

Olsina, L., D. Godoy, D. Lafuente and G. Rossi. (1999). Assessing the quality of academic websites: A case study. The New Review of Hypermedia and Multimedia 5: 81-103.

Pashazadeh F. Hajizeinolabedi M. (2009). Web QEM (WEBQEM) Has A Quantitative Approach To Assessing The Quality And Libraries Of The Library. In: Proceedings of the Conferences of University Libraries Websites. Tehran: Librarian.

Saeid, Mehri, Abdul Azim Abd Ghani, and hasan Selamat. (2011). Rank-Order Weighting of Web Attributes for Website Evaluation. The International Arab Journal of Information Technology 8 (1), 30-38. 